\title{
Conjunctival lymphomas in Japanese monozygotic twins: A case report
}

\author{
NAOYA ISHIBASHI ${ }^{1}$, SATOSHI SUGAYA ${ }^{2}$, HIROMICHI TAKAHASHI ${ }^{3}$, HARUNA NISHIMAKI $^{4}$, \\ YOKO NAKANISHI $^{4}$, YOSHIAKI CHINEN ${ }^{5}$ and TOSHIYA MAEBAYASHI ${ }^{1}$ \\ ${ }^{1}$ Department of Radiology, Nihon University School of Medicine; ${ }^{2}$ Division of Ophthalmology, \\ Department of Visual Sciences, Nihon University School of Medicine; ${ }^{3}$ Division of Hematology and Rheumatology, \\ Department of Medicine, Nihon University School of Medicine; ${ }^{4}$ Department of Oncologic Pathology, \\ Nihon University School of Medicine, Tokyo 173-8610; ${ }^{5}$ Division of Hematology and Oncology, \\ Department of Medicine, Kyoto Prefectural University of Medicine, Kyoto 602-8566, Japan
}

Received May 14, 2018; Accepted October 31, 2018

DOI: $10.3892 / \mathrm{ol} .2018 .9723$

\begin{abstract}
An individual with a twin who has developed leukemia or non-Hodgkin lymphoma (NHL) has an increased risk of developing the same disease, particularly with monozygotic twins. The few reported pairs of twins who developed NHL had similar primary sites and pathological subtypes. Here, we present the first reported cases of primary conjunctival NHL in both female monozygotic twins. Twin 1 was diagnosed with an extranodal marginal zone lymphoma (EMZL; Ann Arbor stage $\mathrm{I}_{\mathrm{E}}$ ) in the right conjunctiva at 25 years old and a subsequent tumor in the left conjunctiva at 39 years, and was also histopathologically diagnosed as EMZL. No infiltration of other organs was detected and both lesions were surgically excised. At the age of 40 years, Twin 2 was diagnosed with an EMZL (Ann Arbor stage $I_{E}$ ) in the right conjunctiva without infiltration of other organs and was treated with external beam radiation therapy rather than surgery. Complete remission was achieved in both twins; neither developed conjunctival recurrences. This study highlights the importance of examining the other, apparently healthy twin when one twin develops conjunctival lymphoma.
\end{abstract}

\section{Introduction}

Siblings, particularly twins, are at similar risk of developing leukemia or non-Hodgkin lymphoma (NHL) $(1,2)$, presumably

Correspondence to: Dr Naoya Ishibashi, Department of Radiology, Nihon University School of Medicine, 30-1 Oyaguchi Kami-cho, Tokyo 173-8610, Japan

E-mail: ishibashi.naoya@nihon-u.ac.jp

Abbreviations: EBRT, external beam radiation therapy; EMZL, extranodal marginal zone lymphoma; FDG-PET/CT, fluorodeoxyglucose-positron emission tomography/computed tomography; NHL, non-Hodgkin lymphoma

Key words: conjunctival lymphoma, monozygotic twins, EMZL due to similarities in both genetic and environmental factors. In a cohort of child cancer survivors including 211 twin pairs (1), the standardized incidence ratio (SIR) for all malignancies in all twins was 8.2 (95\% confidence interval [CI], 3.9-17.1), compared with an SIR of 1.9 (95\% CI, 1.7-2.1) in non-twin siblings, with an even higher SIR in monozygotic twins of 23.3 (9\% CI, 11.1-48.9). Notably, the SIR for NHL was particularly high in monozygotic twins, at $40.5(95 \%$ CI, 5.7-287.5) (1). A few reported cases of NHL occurring in both members of a pair of twins have been pathologically classified as similar types. We herein present the first report of primary conjunctival NHL that developed metachronously in each of a pair of monozygotic twins. Complete remission (CR) was achieved with different therapeutic strategies in each twin.

\section{Case report}

Twin 1 (treated at another hospital). The present team discovered Twin 1's medical history while treating Twin 2. Twin 1's attending physician was subsequently interviewed and the relevant biopsy specimen slides were sent to our hospital and reviewed by the present team.

A tumor associated with papillary changes was detected in the right conjunctiva in a 25-year-old woman and diagnosed as an extranodal marginal zone lymphoma (EMZL) by examination of a biopsy specimen. No infiltration of any other organs was detected and the EMZL was staged as Ann Arbor stage $\mathrm{I}_{\mathrm{E}}$. The tumor was excised and the patient (Twin 1) was closely followed up. At the age of 39 years, an asymptomatic conjunctival tumor was detected in the contralateral upper and lower conjunctiva (Fig. 1) and monitored. It did not regress and was therefore completely excised. Histopathological examination revealed lympho-epithelial lesions with monotonous infiltration of small atypical lymphocytes extending into the epithelium. Reactive follicle formation at the center of the lesion was accompanied by follicular colonization. On immunostaining, the lesion was positive for cluster of differentiation (CD) 20 and negative for CD10. On the basis of these findings, an EMZL was again 
diagnosed (Fig. 2). Detailed protocols of the experimental procedures for Twin 1 are unavailable, but staining was performed and the magnifications are shown. No infiltration of any other organs was detected by either fluorodeoxyglucose-positron emission tomography/computed tomography (FDG-PET/CT) or bone marrow biopsy and the EMZL was staged as Ann Arbor stage $\mathrm{I}_{\mathrm{E}}$. At the time of writing, Twin 1 had been closely followed up for 1.5 years since the most recent surgery, with no recurrence.

Twin 2 (treated at our hospital). Twin 1's monozygotic twin sister, Twin 2, presented with the sensation of a foreign body in the right lower conjunctiva at age 38 years. Three months later, at age 39 years, a tumor with papillary changes was detected in the right lower conjunctiva. Although examination of a biopsy of the same lesion revealed lymphocytic infiltration, no evidence of lymphoma was detected. Twin 2 was closely followed up and a second biopsy of the tumor in the right lower conjunctiva taken at the age of 40 years because the lesion had grown (Fig. 3). Histopathological examination revealed massive infiltration of small to medium-sized lymphocytes with atypical centrocytes under the epithelium. The lesion contained closely packed follicles and no tangible body macrophages were identified in the germinal centers of the reactive follicles. The follicular cells were positive for CD20 and almost negative for CD10. A pattern of CD21 staining was detected in the follicular dendritic cells, which had created well-formed meshworks. Bcl-2 protein was expressed not in the germinal center but in the peripheral zone of follicles. Bcl-6-positive cells in the interfollicular areas were Bcl-2-negative and these Bcl-6-positive cells were the remaining reactive follicular center cells. Ki-67-positive cells had lost polarity and there were a few large centroblastic cells. Thus Twin 2 was diagnosed as EMZL with intense follicular colonization (Fig. 4). No infiltration of any other organs was detected by FDG-PET/CT and the EMZL was staged as Ann Arbor stage $\mathrm{I}_{\mathrm{E}}$. Because this tumor widely involved the conjunctiva and it was believed that the completely excision was difficult, external beam radiation therapy (EBRT) was administered. Because the lesion involved the conjunctival surface in a way that was undetectable by magnetic resonance imaging, the entire conjunctiva was irradiated with a $5-\mathrm{MeV}$ electron beam. A lead shield was placed on the cornea to prevent development of a radiation-induced cataract. CR was achieved by irradiation at a dose of $2 \mathrm{~Gy} /$ fraction to a total dose of $30 \mathrm{~Gy}$. There were no adverse effects of radiation therapy. Twin 2 has been closely followed up for 6 months after this therapy to date, with no recurrence.

Hematoxylin and eosin staining (Twin 2). Sections (4 $\mu \mathrm{m})$ were cut from each paraffin-embedded, formalin-fixed (FFPE) tissue blocks and stained with Mayer's hematoxylin (Sakura Finetek Japan Co., Ltd., Tokyo, Japan) and eosin-floxine (Sakura Finetek Japan Co., Ltd.) using by Tissue-Tek ${ }^{\circledR}$ prisma (Sakura Finetek Japan Co., Ltd.). Mayer's hematoxylin was reacted for $3 \mathrm{~min}$ at room temperature, and eosin-floxine was reacted for $3 \mathrm{~min}$ at room temperature.

Immunohistochemistry (Twin 2). Sections $(4 \mu \mathrm{m})$ were deparaffinized and treated with Envision Flex High $\mathrm{pH}$
A

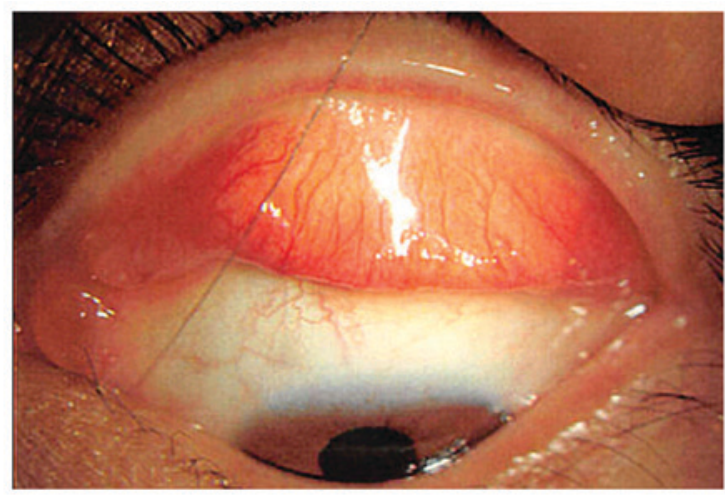

B

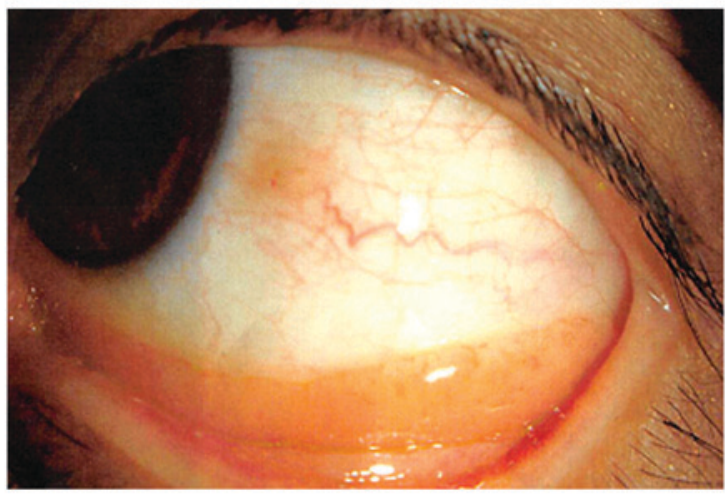

Figure 1. Conjunctival tumors were detected in the contralateral upper and lower conjunctiva. Photographs demonstrating the conjunctival tumors in the upper (A) and lower conjunctiva (B). Detailed magnifications of these photographs are unavailable as they were taken at another hospital.

visualisation system (Dako; Agilent Technologies Inc., Santa Clara, CA, USA), as antigen retrieval, for $20 \mathrm{~min}$ at $97^{\circ} \mathrm{C}$ in a microwave and blocked using Peroxidase-Blocking Solution (Dako; Agilent Technologies, Inc.) at room temperature for $5 \mathrm{~min}$. The immunohistochemical stainings were performed using by Autostainer Link 48 (Dako; Agilent Technologies, Inc.). Primary antibodies were used in the present study as follows: B-cell lymphoma 2 (Bcl2; clone SC-509; host, mouse; Santa Cruz Biotechnology, Inc., Dallas, TX, USA, cat no. M0887; 1:50), Bcl6 (clone, PG-B6p; host, mouse; Dako; Agilent Technologies, Inc.; cat no. IR625), CD10 (clone, 56C6; host, mouse; Novocastra, Leica Microsystems GmbH, Wetzlar, Germany.; cat no. NCL-CD10-270; 1:10), CD20 (clone, L26; host, mouse; Dako; Agilent Technologies, Inc.; cat no. IR604; 1:1,600), CD21 (clone, 1F8; host, mouse; Dako; Agilent Technologies, Inc.; cat no. IR608). Counterstaining was performed with hematoxylin. All of the assays were validated using proper positive controls tonsil FFPE tissue sections. Results were evaluated using a light microscope (BX-41, Olympus Co., Tokyo, Japan). The positive cut-off for all antibodies was considered to be $30 \%$ (3).

Detection of immunoglobulin gene rearrangements by BIOMED-2 study protocols. To analyze immunoglobulin gene clonal rearrangements by multiplex PCR, we used the BIOMED-2 primer system (4). In the BIOMED-2 guidelines, three sets of VH FR regions primers (FR1:6 primers, FR2:7 primers, and FR3: 7 primers) and a JH primer were designed. Furthermore, immunoglobulin kappa chain (IGK) 
A

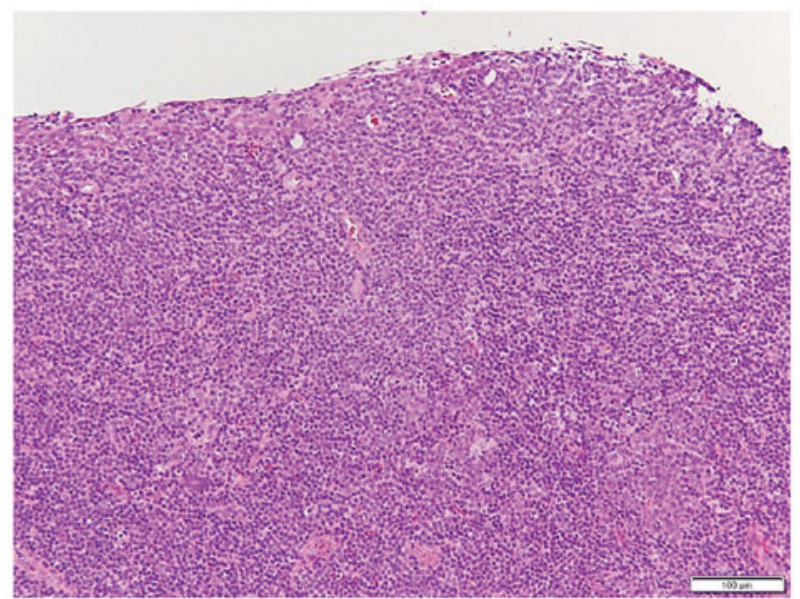

B

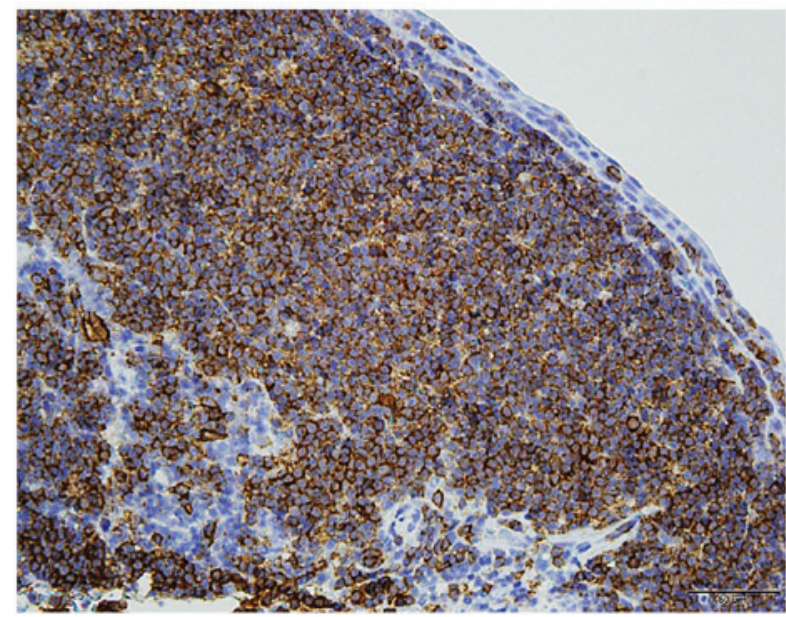

C

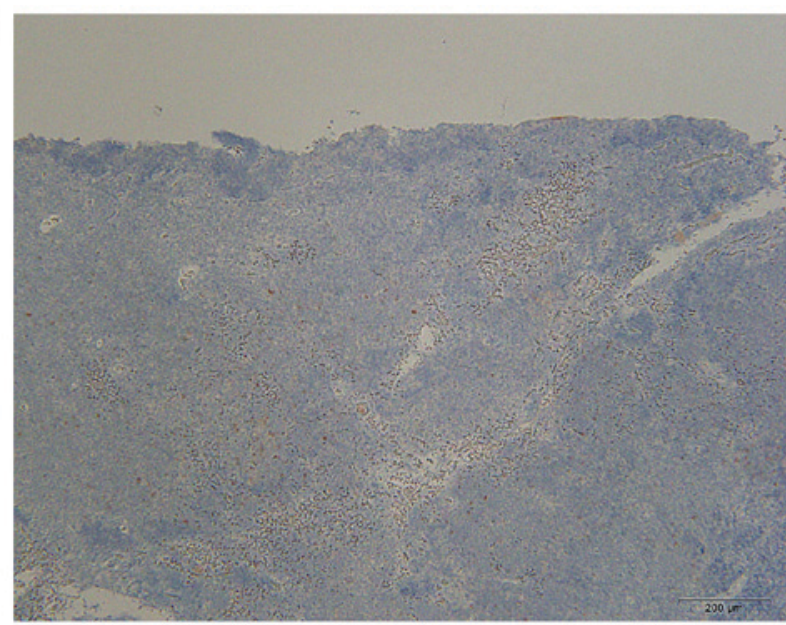

Figure 2. Histological and immunohistochemical findings in Twin 1's conjunctival tumor. (A) Lympho-epithelial lesion with monotonous infiltration of atypical lymphocytes extended into the epithelium and reactive follicle formation at the center of the lesion was accompanied by follicular colonization (magnification, x200; hematoxylin and eosin). (B) Immunohistochemica staining showing the lesion to be diffusely positive for CD20 (magnification, $\mathrm{x} 400$ ). (C) No CD10-positive cells were identified in the interfollicular area (magnification, $\mathrm{x} 100$ ).

VH primers (FR: 6 primers) and two sets of JH primers (JH1: 2 primers and JH2: 1 primer), and immunoglobulin lambda chain (IGL) VH primer and JH primer were prepared as previously reported by Lu et al (5). RNase P was used as the internal control. The PCR products were analyzed by agarose

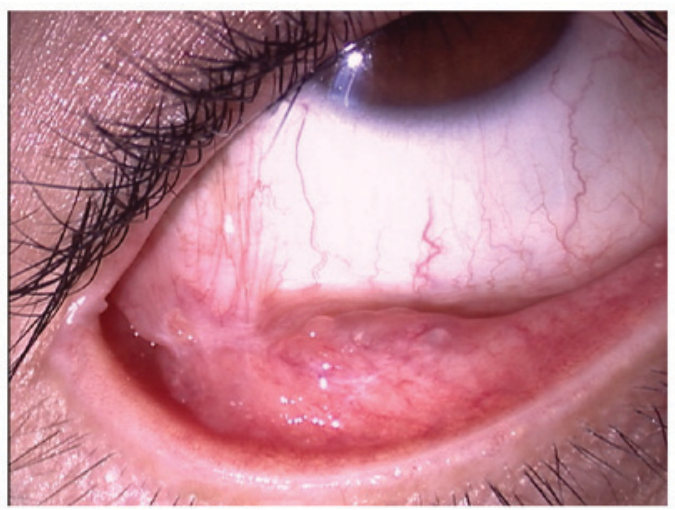

Figure 3. Photograph demonstrating the conjunctival tumor in the lower conjunctiva. Magnification, x10.

gel electrophoreses. Clonal immunoglobulin gene rearrangements were found by multiplex PCR, but the patterns of these rearrangement were different between both Twin 1 and Twin 2. In Twin 1, clonal rearrangement was detected by IGH FR2 primer set, and by IGH FR1 primer set in Twin 2. In both Twin 1 and Twin 2, IGK (kappa chain) were detected but IGL (lambda chain) were absent. Multiplex PCR analysis showed that immunoglobulin kappa light chain was dominant in both twins (data not shown).

Fluorescence in situ hybridization for immunoglobulin heavy chain (IGH)-mucosa associated lymphoid tissue lymphoma translocation gene 1 (MALT1) rearrangement detection. Four-micrometer sections were cut and deparaffinized with xylene. Glass slides were heated at $70^{\circ} \mathrm{C}$ for $10 \mathrm{~min}$. After the hydrophilic procedure and washing, the samples were placed in citric buffer at $98^{\circ} \mathrm{C}$ for $15 \mathrm{~min}$. After washing, proteinaseK solution was added to the samples and incubated at room temperature for $15 \mathrm{~min}$. Next, Cytocell aquarius $\mathrm{t}(14 ; 18)(32.33: 21.31-21.32) /$ IGH-MALT1 dual fusion probe (Cytocell Ltd., Cambridge, UK) was added to the individual samples and the samples were covered with coverslips. After sealing the coverslips, the samples were denatured at $75^{\circ} \mathrm{C}$ for $10 \mathrm{~min}$ and the slides were transferred to a hybridization oven overnight at $37^{\circ} \mathrm{C}$. Further processing included washing and counterstaining with DAPI. Signals were detected using an Axio Imager Z2 with a fluorescent microscope (Carl Zeiss Microscopy, Jena, Germany) with appropriate filters (Chroma Technology Corporation, Bellows Falls, VT, USA). The images were analyzed with the ZEN2 Pro software (Carl Zeiss Microscopy). These results showed the not rearranged IGH-MALT1 signals in both twins' samples (data not shown).

Species-specific real-time PCR for the diagnosis of Chlamydia psittaci (C. psittaci) infection. DNA samples were extract from formalin fixed and paraffin embedded (FFPE) sections using by the commercial kit (GeneRead DNA FFPE kit, Qiagen $\mathrm{GmbH}$, Hilden, Germany). The first PCR reaction was carried out with each DNA by using the AmpliTaq Gold ${ }^{\circledR} 360$ Master Mix (Thermo Fisher Scientific, Inc., Waltham, MA, USA) and the species-specific primers that have been reported by Opota et al (6). Samples were incubated at $95^{\circ} \mathrm{C}$ for $10 \mathrm{~min}$ before being subjected to 40 cycles of denaturation at $95^{\circ} \mathrm{C}$ for 
A

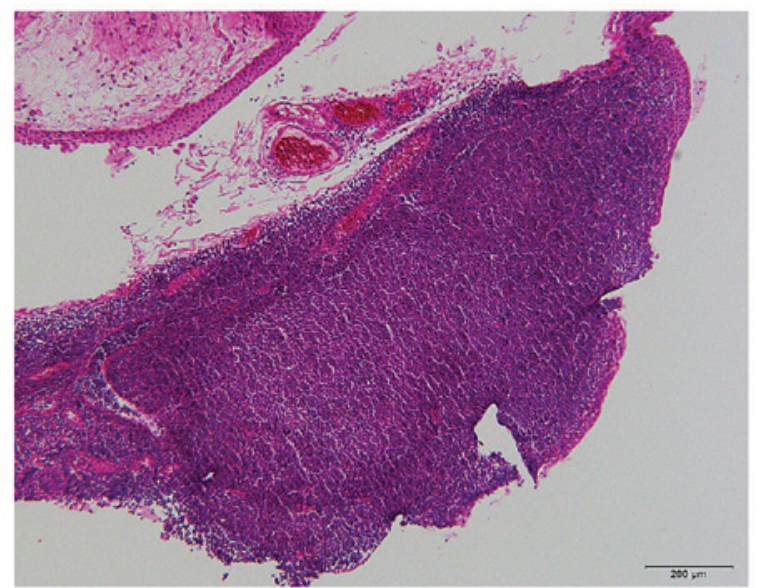

B

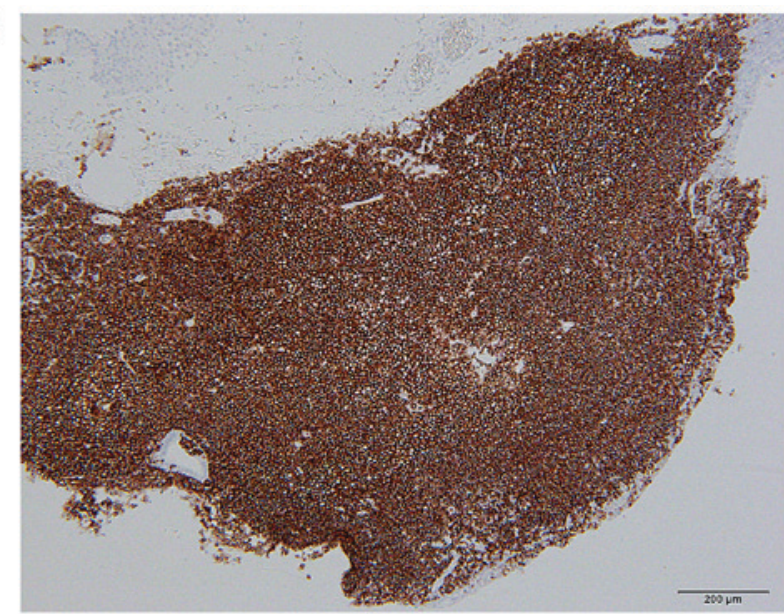

C

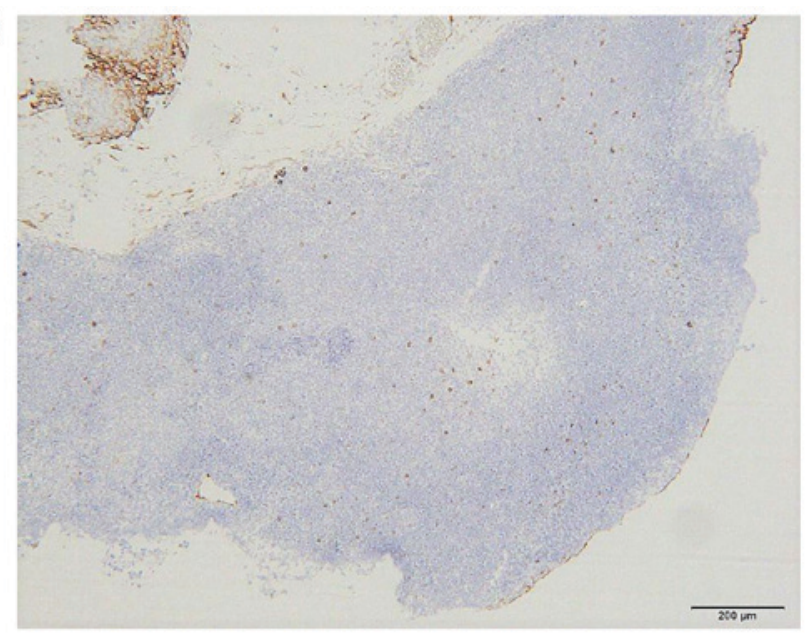

D

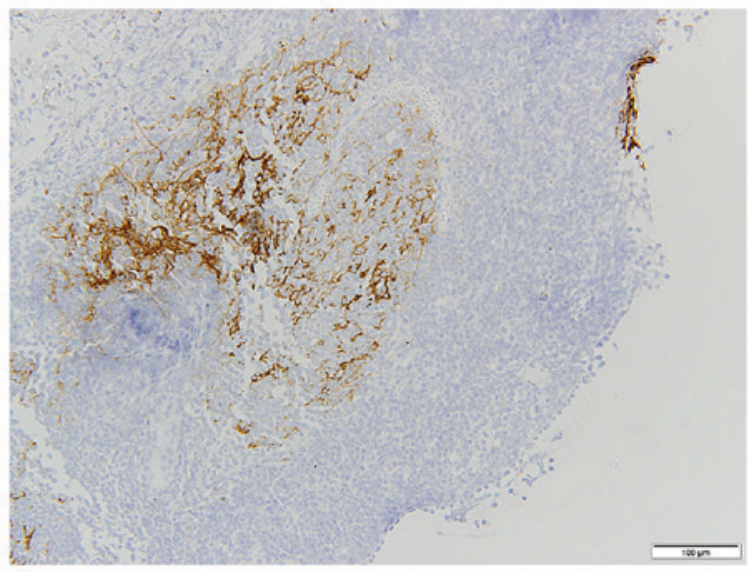

E

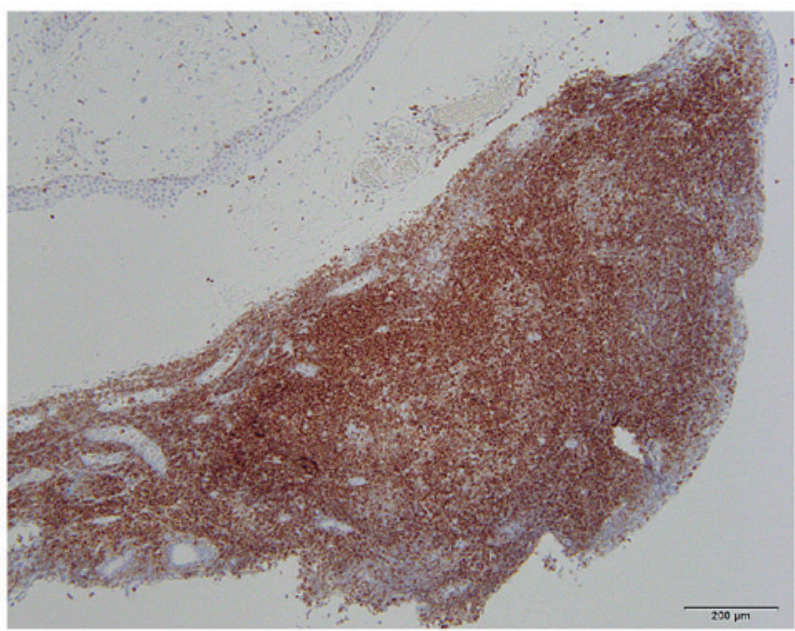

$\mathbf{F}$

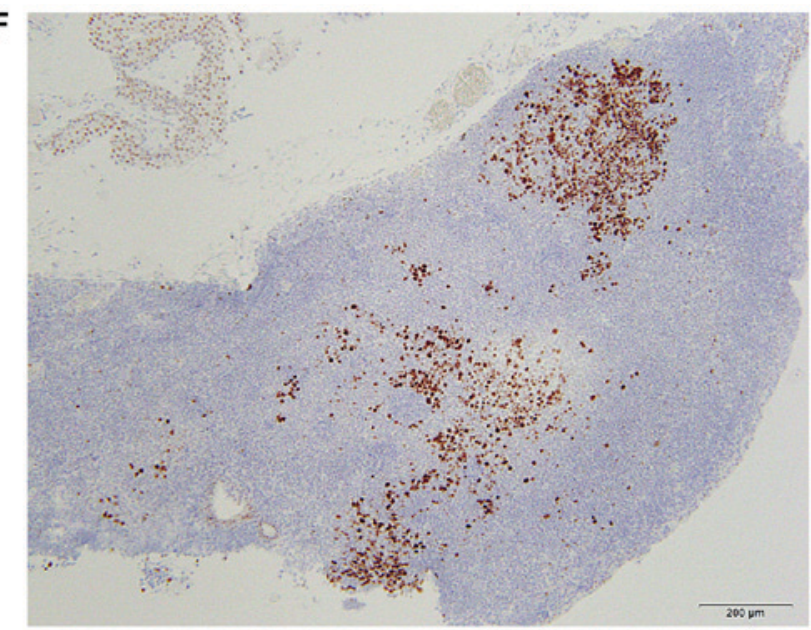

Figure 4. Histological and immunohistochemical findings in Twin 2's conjunctival tumor. (A) Lymphocytes with atypical centrocytes under the epithelium formed large follicles with intense follicular colonization (magnification, x100; hematoxylin and eosin). (B) Immunohistochemical staining showing that these follicular cells are positive for CD20 (magnification, x100) and (C) almost negative for CD10 (magnification, x100). (D) CD21 staining is apparent in follicular dendritic cells, which have created well-formed meshworks (magnification, x200). (E) Bcl-2 protein cells is expressed in the peripheral zone of follicles (magnification, x100). (F) Bcl-6-positive cells is expressed in the interfollicular area (magnification, x100).

$30 \mathrm{sec}$, annealing at $60^{\circ} \mathrm{C}$ for $1 \mathrm{~min}$, and polymerization at $72^{\circ} \mathrm{C}$ for $1 \mathrm{~min}$. The first reaction was performed on a conventional PCR machine (PC808, ASTEC Co. Ltd., Fukuoka, Japan). Two microliters of each resulting product were used as the template in the second semi-nested (snq) PCR $(7,8)$ amplification performed by QuantStudio 3 (Thermo Fisher Scientific, Inc.) with the species-specific primers, as same as the first
PCR reaction, and TaqMan ${ }^{\circledR}$ probes that have been reported by Opota et al (6). TaqMan Copy Number Reference Assay, RNase P, Human (Thermo Fisher Scientific, Inc.) were used as an internal control gene. Although internal control gene RNase $P$ was detected from both Twin 1 and Twin 2 sample DNA, neither $C$. psittaci nor $C$. abortus were detected from both twins (data not shown). 
Table I. Overview of reported twin pairs with non-Hodgkin lymphoma.

Twin 1

\begin{tabular}{|c|c|c|c|c|c|c|c|c|}
\hline \multirow[b]{2}{*}{ Author, year } & \multirow[b]{2}{*}{ Pair } & \multirow[b]{2}{*}{ Twin type } & \multirow[b]{2}{*}{ Sex } & & & \multirow[b]{2}{*}{ (Refs.) } \\
\hline & & & & Histology, invaded organ & $\begin{array}{l}\text { Age, } \\
\text { years }\end{array}$ & Histology, invaded organ & $\begin{array}{l}\text { Age, } \\
\text { years }\end{array}$ & \\
\hline Granet, 1949 & 1 & MZ & $\mathrm{M} / \mathrm{M}$ & ML, rectum & 31 & ML, rectum & 38 & (9) \\
\hline $\begin{array}{l}\text { Schneider } \\
\text { et al, } 1995\end{array}$ & 2 & $\mathrm{MZ}$ & $\mathrm{F} / \mathrm{F}$ & T cell lymphoma, skin & 46 & T celllymphoma, skin & 47 & $(10)$ \\
\hline $\begin{array}{l}\text { Jensen et al, } \\
1997\end{array}$ & 3 & MZ & $\mathrm{F} / \mathrm{F}$ & EBV positive NHL, CNS & 18 & EBV positive NHL, CNS & 19 & $(11)$ \\
\hline $\begin{array}{l}\text { Salawu et al, } \\
1997\end{array}$ & 4 & MZ & $\mathrm{M} / \mathrm{M}$ & $\begin{array}{l}\text { Burkitt's lymphoma, } \\
\text { nodal }\end{array}$ & 8 & $\begin{array}{l}\text { Burkitt's lymphoma, } \\
\text { nodal }\end{array}$ & 11 & (12) \\
\hline $\begin{array}{l}\text { Marco et al, } \\
1999\end{array}$ & 5 & MZ & $\mathrm{M} / \mathrm{M}$ & $\begin{array}{l}\text { Follicular lymphoma, } \\
\text { nodal }\end{array}$ & 48 & $\begin{array}{l}\text { Follicular lymphoma, } \\
\text { nodal }\end{array}$ & 48 & (13) \\
\hline $\begin{array}{l}\text { Chakravarti } \\
\text { et al, } 2005\end{array}$ & 6 & DZ & $\mathrm{M} / \mathrm{F}$ & $\begin{array}{l}\text { Follicular lymphoma, } \\
\text { nodal }\end{array}$ & 52 & $\begin{array}{l}\text { Follicular lymphoma, } \\
\text { salivary gland }\end{array}$ & 53 & (14) \\
\hline $\begin{array}{l}\text { Dickinson } \\
\text { et al, } 2011\end{array}$ & 7 & $\mathrm{MZ}$ & $\mathrm{M} / \mathrm{M}$ & $\begin{array}{l}\text { Marginal zone } \\
\text { lymphoma, skin }\end{array}$ & 45 & $\begin{array}{l}\text { Marginal zone } \\
\text { lymphoma, skin }\end{array}$ & 45 & $(15)$ \\
\hline \multirow[t]{2}{*}{$\begin{array}{l}\text { Bahig et al, } \\
2016\end{array}$} & 8 & MZ & $\mathrm{F} / \mathrm{F}$ & $\begin{array}{l}\text { Marginal zone } \\
\text { lymphoma, skin }\end{array}$ & 18 & $\begin{array}{l}\text { Marginal zone } \\
\text { lymphoma, skin }\end{array}$ & 25 & (16) \\
\hline & $\begin{array}{l}\text { The present } \\
\text { case }\end{array}$ & MZ & $\mathrm{F} / \mathrm{F}$ & $\begin{array}{l}\text { Marginal zone } \\
\text { lymphoma, conjunctiva }\end{array}$ & $\begin{array}{c}25 \text { and } \\
39\end{array}$ & $\begin{array}{l}\text { Marginal zone } \\
\text { lymphoma, conjunctiva }\end{array}$ & 40 & \\
\hline
\end{tabular}

MZ, monozygotic; DZ, dizygotic; ML, malignant lymphoma not otherwise specified; EBV, Epstein-Barr virus; NHL, non-Hodgkin lymphoma not otherwise specified; CNS, central nervous system.

\section{Discussion}

When one member of a twin pair develops leukemia or NHL, the other member is at increased risk of developing the same disease. A cohort study on familial risk of NHL showed that the SIR for lifetime cumulative risk of NHL in siblings of an individual with NHL is 1.6 (95\% CI, 1.2-1.9), compared with a cumulative lifetime risk for twins, depending on sex and age at diagnosis, of 3.1-12.9\% (2). Possible reasons for both members of a pair of twins developing NHL include genetic factors, such as chromosomal translocation, and exposure to similar environmental factors as a result of living in the same region. Only eight instances of both members of a pair of twins developing NHL have been reported (Table I) (9-16). In all these cases, both twins had similar primary sites, the commonest being the skin, which was affected in three pairs. Moreover, both members of each of the eight twin pairs had similar pathological subtypes. No cases of NHL of the conjunctiva in twins have been reported to date. The current case report is the first to document the development of conjunctival NHL in monozygotic twins.

NHL is reportedly associated with several chromosomal translocations and genetic factors may be considered to be responsible in our pair of twins. In recent years, to diagnose B-cell lymphoma, the immunoglobulin gene rearrangement detection system is used as a valuable tool (5). Our both twins have clonal B-cell immunoglobulin gene rearrangements, but the patterns of these rearrangements were different between Twin 1 and Twin 2. Recently, $t(14 ; 18)$ (q32;q21) involving the IgH/MALT1 has been reported in ocular adnexal mucosa-associated lymphoid tissue (MALT) lymphoma (17). However, our both twins were negative for $\mathrm{t}(14 ; 18)(\mathrm{q} 32 ; \mathrm{q} 21)$.

Studies of monozygotic twins, who share a common genome, provide an effective way of assessing the potential contribution of environmental factors to NHL development. According to a questionnaire survey on medical history (e.g., infections and atopic disease) and microbial exposure history (e.g., sucking on a pacifier) in 162 twin pairs with discordant development of NHL, the risk of NHL was higher in the twin who had been more frequently exposed to microbes than their co-twin (18). Conjunctival lymphoma is believed to be caused by prolonged antigen stimulation resulting from chronic conjunctival infection with Chlamydia psittaci and other organisms, causing loss of B-lymphocyte control and $80 \%$ of ocular adnexal lymphoma samples carried C. psittaci DNA (19). Therefore to detect $C$. psittaci infection, we performed species-specific real-time PCR by using the primers that have been reported by Opota et al recently (6). However, our both twins were negative for $C$. psittaci in real-time PCR. Helicobacter pylori is associated with gastric MALT lymphoma but has not been identified in any reported cases of conjunctival MALT lymphoma (20). Because the twins in this case report lived together until Twin 1 developed her first conjunctival lymphoma at age 25 years, Twin 2 might have the another chronic infection at living alone. Autoimmune disorders such as Sjögren syndrome are also reportedly associated with conjunctival lymphoma; however, our twins had no history of such diseases. The commonest 
subtype of conjunctival lymphoma is EMZL, accounting for $81 \%$ of all cases, whereas the second most common is follicular lymphoma (FL), accounting for $8 \%$ (21). The incidence of FL is lower in Asian countries, including Japan, than in the West, and only four cases of conjunctival FL in Japanese individuals have been reported to date (22-25). In the current twins, both NHL in the conjunctiva was EMZL.

EBRT is a highly effective and commonly administered therapeutic strategy for conjunctival lymphoma; nonetheless, complete surgical excision followed by monitoring is also sometimes performed. However, lymphoma cells may infiltrate the surrounding tissues at a microscopic level, resulting in a high recurrence rate in the absence of additional treatment, approximately one in three patients reportedly developing progression or recurrence during a 3-year follow-up $(21,26)$. The total radiation dose of $30 \mathrm{~Gy}$ is generally considered sufficient to successfully and safely control conjunctival EMZL (27,28). In the current Twin 1, NHL developed in the contralateral conjunctiva 13.5 years after complete excision of the first NHL deposit; however, no further recurrence has been identified in either conjunctiva in the 1.5 years since the second surgery. The current Twin 2 was treated with EBRT alone, receiving a total dose of $30 \mathrm{~Gy}$, and has since shown no recurrence in either conjunctiva. Ocular adnexal EMZL may develop in the contralateral orbit, the reported incidence being $6.4 \%$ even after radiation therapy (28). However, the prognosis of ocular adnexal EMZL is favorable, with a 10-year overall survival rate of approximately $95.3 \%$ (28). CR was achieved in both twins in the current case report with different therapeutic strategies being used. Further follow-up of both twins is essential.

We here provide the first reported cases of primary conjunctival NHL occurring metachronously in the conjunctiva of each of a pair of monozygotic twins. When NHL occurs in one of a twin pair, the other twin is at increased risk of developing NHL. When conjunctival lymphoma, which causes few symptoms, develops in a twin, it is therefore important to examine the other, apparently healthy twin.

\section{Acknowledgements}

Not applicable.

\section{Funding}

No funding was received.

\section{Availability of data and materials}

The datasets used and/or analyzed during the current study are available from the corresponding author on reasonable request.

\section{Authors' contributions}

NI treated Twin 2 and analyzed the twins' data, as well as being a major contributor to writing the manuscript. SS biopsied the conjunctiva of Twin 2. HT examined Twin 2. HN and YN performed the histological examinations of the twins' samples. YC examined Twin 1. TM treated Twin 2. All authors read and approved the final manuscript.

\section{Ethics approval and consent to participate}

The patients provided written informed consent.

\section{Patient consent for publication}

The patients provided written informed consent.

\section{Competing interests}

The authors declare that they have no competing interests.

\section{References}

1. Kadan-Lottick NS, Kawashima T, Tomlinson G, Friedman DL, Yasui Y, Mertens AC, Robison LL and Strong LC: The risk of cancer in twins: A report from the childhood cancer survivor study. Pediatr Blood Cancer 46: 476-481, 2006.

2. Fallah M, Kharazmi E, Pukkala E, Tretli S, Olsen JH, Tryggvadottir L, Sundquist K and Hemminki K: Familial risk of non-Hodgkin lymphoma by sex, relationship, age at diagnosis and histology: A joint study from five Nordic countries. Leukemia 30: 373-378, 2016.

3. Choi WW, Weisenburger DD, Greiner TC, Piris MA, Banham AH, Delabie J, Braziel RM, Geng H, Iqbal J, Lenz G, et al: A new immunostain algorithm classifies diffuse large B-cell lymphoma into molecular subtypes with high accuracy. Clin Cancer Res 15: 5494-5502, 2009.

4. van Dongen JJ, Langerak AW, Brüggemann M, Evans PA, Hummel M, Lavender FL, Delabesse E, Davi F, Schuuring E, García-Sanz R, et al: Design and standardization of PCR primers and protocols for detection of clonal immunoglobulin and T-cell receptor gene recombinations in suspect lymphoproliferations: Report of the BIOMED-2 Concerted Action BMH4-CT98-3936. Leukemia 17: 2257-2317, 2003.

5. Lu C, He Q, Zhu W, Fu C, Zhou J, Tao Y, Liu S and Xiao D: The value of detecting immunoglobulin gene rearrangements in the diagnosis of B-cell lymphoma. Oncotarget 8: 77009-77019, 2017.

6. Opota O, Jaton K, Branley J, Vanrompay D, Erard V, Borel N, Longbottom D and Greub G: Improving the molecular diagnosis of Chlamydia psittaci and Chlamydia abortus infection with a species-specific duplex real-time PCR. J Med Microbiol 64: 1174-1185, 2015.

7. Nakanishi Y, Shimizu T, Tsujino I, Obana Y, Seki T, Fuchinoue F, Ohni S, Oinuma T, Kusumi Y, Yamada T, et al: Semi-nested real-time reverse transcription polymerase chain reaction methods for the successful quantitation of cytokeratin mRNA expression levels for the subtyping of non-small-cell lung carcinoma using paraffin-embedded and microdissected lung biopsy specimens. Acta Histochem Cytochem 46: 85-96, 2013.

8. Iida Y, Masuda S, Nakanishi Y, Shimizu T, Nishimaki H, Takahashi M, Hikichi M, Maruoka S, Gon Y, Takahashi N and Hashimoto S: Clinicopathological characteristics of thyroid transcription factor 1-negative small cell lung cancers. Hum Pathol 79: 127-134, 2018.

9. Granet E: Simple lymphoma of the sphincteric rectum in identical twins. J Am Med Assoc 141: 990, illust, 1949.

10. Schneider BF, Christian M, Hess CE and Williams ME: Familial occurrence of cutaneous T cell lymphoma: A case report of monozygotic twin sisters. Leukemia 9: 1979-1981, 1995.

11. Jensen MK, Koch-Henriksen N, Johansen P, Varming K, Christiansen CB and Knudsen F: EBV-positive primary central nervous system lymphomas in monozygote twins with common variable immunodeficiency and suspected multiple sclerosis. Leuk Lymphoma 28: 187-193, 1997.

12. Salawu L, Fatusi OA, Kemi-Rotimi F, Adeodu OO and Durosinmi MA: Familial Burkitt's lymphoma in Nigerians. Ann Trop Paediatr 17: 375-379, 1997.

13. Marco F, Manjón R, Richard C, Mazorra F, García-Valtuille A, Delgado MD, Loyo ML, Cuadrado MA and Zubizarreta A: Simultaneous occurrence of follicular lymphoma in two monozygotic twins. Br J Haematol 107: 461-462, 1999. 
14. Chakravarti A, Leslie WT and Venugopal P: Relapsed non-Hodgkin lymphoma in fraternal twins managed successfully with rituximab maintenance therapy. Clin Adv Hematol Oncol 3: 136-140, 2005

15. Dickinson PD, Patel A, Wootton C, Bessell EM and O'Connor S: Primary cutaneous marginal zone B cell lymphoma in monozygotic twins. BMJ Case Rep 3: pii: bcr1120103515, 2011.

16. Bahig H, Petrogiannis-Haliotis T, Pehr KL and Roberge D Primary cutaneous B-cell lymphoma in young monozygotic twins: A case report. J Cutan Med Surg 20: 582-585, 2016.

17. Streubel B, Lamprecht A, Dierlamm J, Cerroni L, Stolte M, Ott G, Raderer M and Chott A: T(14;18)(q32;q21) involving IGH and MALT1 is a frequent chromosomal aberration in MALT lymphoma. Blood 101: 2335-2339, 2003.

18. Wang J, Mack TM, Hamilton AS, Hwang AE, Nathwani BN, Masood K, Buchanan LH, Bernstein L, Deapen DM, Martínez-Maza O and Cozen W: Common immune-related exposures/conditions and risk of non-Hodgkin lymphoma: A case-control study of disease-discordant twin pairs. Am J Epidemiol 182: 417-425, 2015.

19. Ferreri AJ, Guidoboni M, Ponzoni M, De Conciliis C, Dell'Oro S, Fleischhauer K, Caggiari L, Lettini AA, Dal Cin E, Ieri R, et al: Evidence for an association between Chlamydia psittaci and ocular adnexal lymphomas. J Natl Cancer Inst 96: 586-594, 2004

20. Sjö NC, Foegh P, Juhl BR, Nilsson HO, Prause JU, Ralfkiaer E, Wadström T and Heegaard S: Role of Helicobacter pylori in conjunctival mucosa-associated lymphoid tissue lymphoma. Ophthalmology 114: 182-186, 2007.

21. Kirkegaard MM, Coupland SE, Prause JU and Heegaard S: Malignant lymphoma of the conjunctiva. Surv Ophthalmol 60 444-458, 2015

22. Azumi A, Hirai K, Tamura Y, Saito K, Yamamoto H, Negi A and Obayashi C: A case of follicular lymphoma derived from the conjunctiva. Nippon Ganka Gakkai Zasshi 106: 420-425, 2002.
23. Takahira M, Okumura H, Minato H, Urushisaki N, Sakurai M and Sugiyama K: Primary conjunctival follicular lymphoma treated with the anti-CD20 antibody rituximab and low-dose involved-field radiotherapy. Jpn J Ophthalmol 51: 149-151, 2007.

24. Otomo T, Fuse N, Ishizawa K, Seimiya M, Shimura M and Ichinohasama R: Japanese case of follicular lymphoma of ocular adnexa diagnosed by clinicopathologic, immunohistochemical, and molecular genetic techniques. Clin Ophthalmol 4: 1397-1402, 2010.

25. Abd Al-Kader L, Sato Y, Takata K, Ohshima K, Sogabe Y, Fujii K, Iwaki N and Yoshino T: A case of conjunctival follicular lymphoma mimicking mucosa-associated lymphoid tissue lymphoma. J Clin Exp Hematop 53: 49-52, 2013.

26. Baldini L, Blini M, Guffanti A, Fossati V, Colombi M, La Targia ML, Bertoni F, Alietti A, Neri A and Bertoni G: Treatment and prognosis in a series of primary extranodal lymphomas of the ocular adnexa. Ann Oncol 9: 779-781, 1998.

27. Hata M, Omura M, Koike I, Tomita N, Iijima Y, Tayama Y, Odagiri K, Minagawa Y, Ogino I and Inoue T: Treatment effects and sequelae of radiation therapy for orbital mucosa-associated lymphoid tissue lymphoma. Int J Radiat Oncol Biol Phys 81: $1387-1393,2011$

28. Hashimoto N, Sasaki R, Nishimura H, Yoshida K, Miyawaki D, Nakayama M, Uehara K, Okamoto Y, Ejima Y, Azumi A, et al: Long-term outcome and patterns of failure in primary ocular adnexal mucosa-associated lymphoid tissue lymphoma treated with radiotherapy. Int J Radiat Oncol Biol Phys 82: 1509-1514, 2012. 